\title{
Impact of Power System Reform on the Investment Strategy of Power Grid Enterprises and Countermeasures
}

\author{
Zhou Jinglong, Yan Pengfei, Yang Chenguang \\ State Grid Hebei Electric Power Company, Shijiazhuang Hebei China, 050021
}

Keywords: Power system reform; Grid enterprise; Investment strategy; Coping analysis

\begin{abstract}
In recent years, China has intensified its reform on power system and the supervision of total income of power grid enterprises. The reform of electric power system is intended to establish an independent electricity price system to promote the development of electricity market and improve the scientificity, institutionalization and integrity of electricity price regulation, in the meantime, bring impact on the operation and profit model of power grid enterprises. In this context, the scheme and characteristics of power system reform is analyzed in this paper by comparing domestic and foreign power system reform models and the analysis of the influence of investment strategy of power grid enterprises on investment decision-making, investment execution and post-investment evaluation under power system reform and ways to meet the needs of investment in power grid enterprises, investment strategies, business concept change and new power system reform countermeasures are proposed.
\end{abstract}

\section{Introduction}

With the reform of power system and open market, main power supply enterprises are also facing fierce market competition. Comprehensive analysis results show that there are obvious advantages in power grid enterprises, but grid companies also bear greater social responsibility. China's power system reform mainly draws on the experience and practice of other countries. With full consideration of the characteristics of China's economic system [1], based on the overall reform and taking the Constitution as a guide, the full implementation of power system reform should be conducted. Since the reform and opening up, the state implemented deregulation on power system supervision and state-owned monopoly which has lower efficiency. There is no fundamental change, so a comprehensive analysis of power system reform problems is very important. First is the impact of power system reform on the investment strategy of power grid enterprises.

China's power grid enterprises are still in the stage of investment and development. Therefore, in order to improve the safety and reliability of power grid to meet the demand for power load growth, power companies need to invest human resources and financial resources every year to improve and maintain power grid. The investment of grid enterprises is different from that of other industries. The investment amount of grid enterprises is relatively large. The period and payback period are relatively long. When the investment of grid enterprises is wrong, it will cause huge waste of resources and the loss is irreversible. But with no investment, power grid companies cannot make effective operation, so power grid enterprise investment problem has become very important. Of course, there are many factors that affect the investment of power grid enterprises including natural, man-made, social, and economic factors [2], and grid business investment decision-making process, operation process and construction process can make the actual effect of investment beneath the expected effect. In this paper, the influence of power system reform on the investment strategy of power grid companies is analyzed, and by comparing the reform of foreign power system, problems are found and the corresponding solutions are sought to improve the investment strategy of power grid enterprise. 


\section{Impact of power system reform}

Since China's accession to the WTO, China's electricity market has become possible. But we now face an important issue, which is, how to enhance the competitiveness of China's power companies. Power industry belongs to basic industry in China's industry sector, and power system is the basis of power industry. Power system includes power plants, power grids, distribution networks, power consumers. The four links are interconnected and integral. There is a serious shortage in China's power system supervision. Some countries or regions use cost regulation. Grid business profits can be guaranteed as much as possible, so the innovation in power grid investment has been greatly improved. With market rules and structural changes, market supervision theory and model are constantly changing and produce some commonality. With the development of the times, a new regulatory model is gradually applied, which is incentive control model. This model cannot only be used in the management of power system, also be used in natural gas, water supply and other industries. Power regulation mode of foreign electricity market is summarized in Table 1.

Table 1 Foreign power market power regulation model

\begin{tabular}{ll}
\hline Country & \multicolumn{1}{c}{ Power regulation model } \\
Australia 's power transmission & Revenue cap control \\
Australia's electricity distribution & Revenue cap, price cap control \\
US Washington State & Investment return control \\
New Zealand & Revenue cap control \\
Philippine power transmission & Revenue cap control \\
Philippine electricity distribution & Price cap control \\
US California & Slide revenue control \\
\hline
\end{tabular}

Foreign experience has brought us great revelation, and we find such a law that when reform target changes, legislative focus has also changed. If the US electricity is sufficient, they will lower the price. So China's power reform can also be according to this law. The reform of power system will affect the major power grid company's traditional business model for the electricity market to bring new weather. Therefore, we should attach importance to the impact of power system reform to build a good grid company's market competition model [3]. Electric power is the basic industry in China and power system reform is particularly important because power reform cannot only strengthen power management, but also improve the level of economic development.

Electric power system reform will bring more power markets' access and the grid company's existing model will be broken. Therefore, the investment strategy of power grid enterprises will also face new requirements. Grid enterprises, as the most basic business in power industry, have great responsibility for electricity transmission and sale, and at the same time, they also bear the important task of social and economic development. With the continuous reform of China's power system, the role of power grid enterprises has also undergone tremendous changes gradually from single manager into multiple roles of service, breaking the traditional model, and also changed power enterprises' inherent impression in people's eyes. The reformed new power system has realized the opening and development of electricity market and changed the original subject and function of electricity market. At present, grid enterprise market competition is fierce and major power grid companies can only improve their own service model in order to win in operating results, economic development and overall strength.

\section{Investment strategy of power grid enterprises}

By contrast, we can find that grid companies are completely different from other businesses, and electricity production and consumption are proportional. Power cannot be stored as other products, but also cannot be stocked like other products in supply and demand imbalance. This feature 
determines the power from power generation, transmission to power distribution and the final power consumption must be completed at the same time. They must be an interconnected and complete system. So power industry is usually "natural monopoly", which is also to maintain and protect the system's safe and stable operation. The largest economic characteristic of power industry is its scale, which is the basis of power industry. The structure of power industry is like a spider web covering every corner of life, and its structure is like a network of other public utilities. The coverage of network structure is a network economy, and scale economy is the biggest feature of the mesh mechanism. It needs low cost. As long as the enterprise size is large enough, it not only can have a lower cost, but can have a higher interest. From long-term development point of view, the purpose of investment is to obtain future uncertain interests, and sacrifice current interests. It is precisely because of this that the investment will have a different nature and risk. Sacrifice is happening now, and profit is sure to wait until later, and the size of the profit is often uncertain.

Power grid enterprise investment has its distinctive characteristics. First, huge number of funds is invested by grid enterprises and power grid enterprises are capital-intensive. The matching equipment needs higher funds. The coverage area and the occupied land all require a lot of space and also a lot of human resources. Second, the construction of grid enterprises is a long job [4], so grid companies must plan every step of the development. There must be a long and reliable plan. Every step needs to be meticulous, perfect and reliable. If there is a problem in construction leading to the delayed construction of power grid, it will increase the risk of future profits. Another feature of grid enterprise is that investment payback period is too long, and grid business has a certain social welfare. Currently the government customizes the price for grid enterprises, which is difficult to show the real cost of operating grid business. If coal prices rise, grid electricity price will rise, but the final cost pressure of need to be borne by power grid enterprises. Power grid enterprises reduce its profit margins because of the impact of various interests, resulting in slow recovery of funds, and power grid companies will also be affected by investment capacity. Grid companies' investment flexibility is relatively poor. If the investment direction is wrong, it not only cannot be adjusted, and cannot be compensated in other forms. This will result in land and capital waste. A variety of uncertainties will make the investment strategy of grid companies become complex and difficult to operate.

\section{Coping Strategies Analysis of Power Grid Enterprises Investment}

With the reform of power system, the investment in power grid enterprises has also undergone tremendous changes. In international power reform, the West is the first to make institutional reform. A wide range of opened grid market also brought creative change [5]. Especially in Britain, in 1987 the United Kingdom began to discuss power system reform. At the same time, the United Kingdom completely opened the market and separated the sale of electricity business, so power domain came into a competitive model. Now the UK has a number of retail power grid companies, of which the top six accounts for about $90 \%$ of market share, which is shown in Table 2. 
Table 2 Market share in different countries

\begin{tabular}{|c|c|c|c|}
\hline Name & $\begin{array}{l}\text { Number } \\
\text { customers } \\
\text { (millions) }\end{array}$ & of Parent company & Market share $\square$ \\
\hline British Gas & 20 & Cemtrica & $21 \%$ \\
\hline SSE & 9.6 & $\begin{array}{l}\text { SSE } \\
\text { Group }\end{array}$ & $18 \%$ \\
\hline EDF Energy & 5.7 & EDF & $14 \%$ \\
\hline E.ON UK & 5.3 & E.ON & $18 \%$ \\
\hline Npower & 6.5 & RWE & $16 \%$ \\
\hline Scottish Power & 5.2 & Iberdrola & $12 \%$ \\
\hline
\end{tabular}

Power grid enterprise investment is a complex process and many factors need to be considered. The most influential and direct factor is grid business profits and liabilities. On the basis of determining the overall development goal of power grid enterprises, it changes the direction of investment strategy of power grid enterprises and integrates the influence of power system reform, and finally integrates a set of perfect investment strategy for power grid enterprises. There are many factors that affect the investment income of grid enterprise, and each uncertainty factor will cause immeasurable loss, so we should strengthen risk management. Risk management has become a must to strengthen enterprise. The most important in risk management is investment risk, which may have impact on power enterprises' development and profit. From rational staff allocation, rigorous review criteria, protection of decision-making principles and other aspects, clear power grid enterprise investment, which protects the scientificity of power grid enterprise investment, clears the purpose of power grid investment strategy and reduces risk.

\section{Conclusion}

With the continuous innovation and deepening of power system, power grid enterprises are facing new competition and shock. To gain a firm foothold, power companies must break traditional concept and constantly enhance their own sense of competition. Deepen the reform of power system and rationally reduce the price. Promoting the relevant work is an effective protection to reduce power grid enterprise investment risk. Huge amount of investment and low regulation in power grid enterprises make the use of reasonable investment model and strong investment capacity for power grid enterprise investment necessary to bring greater protection. Improve power system-related laws and regulations and make power control as the basis for reform. At present, China's power grid enterprises accelerate the pace of investment and the significance of electricity regulation is more and more important. We need to combine domestic and international power system reform experience to adjust electricity market supervision environment. For the characteristics of power market, views are given for power grid investment strategy to make grid investment more reasonable. The study of foreign electricity market can not only provide advice for China's power grid enterprise investment decision-making, but also can improve the structure of China's power transmission and distribution.

\section{References}

[1] Shen Hongyu, Chen Jin, Gui Sanrong. Effects and countermeasures of the new round of power reform on the distribution network planning of power grid enterprises [J]. Electric Power Construction, 2016, 37 (3): 47-51.

[2] Liu Xiaqing. Strategic reorganization of China's power market model selection and power grid 
enterprises [D]. Hunan University, 2003.

[3] Gui Xiaoqiang, Tang Wensheng, Guo Hailin. The main practice of strengthening the precise investment of power grid [J]. Jiangxi Electric Power, 2017, 41 (5): 28-29.

[4] Chen Feng, Zhang Yutian. Influence and countermeasures analysis of transmission and distribution price reform on the financial management of power grid enterprises [J]. Commercial economy, 2017 (1): 55-56.

[5] Liu Jianmin, Wang Dong, Li Shenwei. Comprehensive impact and optimization control research of transmission and distribution price reform on power grid enterprises [J]. Management observation, 2017 (1): 23-25. 